\title{
Sounding the Alarm: Government of the \\ Republic of Namibia $v$ LM and Women's Rights \\ during Childbirth in South Africa
}

\section{Pickles*}

\section{P.E.R}

Pioneer in peer-reviewed, open access online law publications

Author

Camilla Pickles

Affiliation

University of Johannesburg

South Africa

Email camilla.pickles@gmail.com

Date of submission

25 January 2018

Date published

10 August 2018

Editor Prof C Rautenbach

How to cite this article

Pickles C "Sounding the Alarm: Government of the Republic of Namibia v LM and Women's Rights during Childbirth in South Africa" PER / PELJ 2018(21) - DOI

http://dx.doi.org/10.17159/17273781/2018/v21i0a4303

\section{Copyright}

DOI

http://dx.doi.org/10.17159/1727-

3781/2018/v21i0a4303

\section{Abstract}

Government of the Republic of Namibia v LM [2014] NASC 19 (hereafter the $L M$ case) concerns the involuntary sterilisation of women during childbirth. The Supreme Court of Namibia found that obtaining consent during the height of labour is inappropriate because labouring women lack the capacity to consent because of the intensity of their labour pains. This article recognises that the $L M$ case may make its way into current litigation strategies against involuntary sterilisations in South Africa and for this reason I evaluate the soundness of the court's reasoning in the $L M$ case. I argue that the court relied on the harmful gender stereotype that labouring women lack the capacity to make decisions, I expose this stereotype as baseless and demonstrate the harmful consequences of its perpetuation. Finally, I demonstrate why the reasoning in the $L M$ case is particularly problematic in the South African context, and I conclude that the adoption of this sort of reasoning will result in many women facing serious injustices, because it strikes at the core of a woman's agency during childbirth.

\section{Keywords}

Involuntary sterilisation; childbirth; informed consent; capacity; obstetric violence; human rights. 


\section{Introduction}

Government of the Republic of Namibia $v L M^{1}$ (hereafter the $L M$ case) concerns a claim for damages arising out of the involuntary sterilisations performed on three women during childbirth. The Supreme Court of Namibia found that obtaining consent for sterilisation procedures during the height of labour is inappropriate because women lack the capacity to provide consent during this time as a result of their experiencing labour pains. ${ }^{2}$ The court recognised that sterilising women without their informed consent violates their rights to found a family, their dignity and their bodily integrity. ${ }^{3}$

The $L M$ case has been identified as the first of its kind in sub-Saharan Africa, and the judgment is considered to be significant because there is similar litigation taking place in other parts of Africa, including South Africa. ${ }^{4}$ The $L M$ case therefore sets the tone for subsequent litigation concerning involuntary sterilisation and women's reproductive healthcare rights more generally. Badul and Strode understand this case to be a victory for patients' rights and view it as adding to existing patient protections. ${ }^{5}$ They assert that the $L M$ case adds to the current body of law relevant to informed consent because it requires the information provided to the patient to be recorded and because it recognises that obtaining consent during labour does not promote patient autonomy, since decisions tend to be rushed in those circumstances. ${ }^{6}$ Kangaunde and Tucker view this judgment as affirming the reproductive rights of women. ${ }^{7}$ Nair suggests that litigation on this issue is an important step towards recognising the reproductive rights of HIV-positive women, that it may encourage a shift in state policies, and that it may increase respect for reproductive choices more generally. ${ }^{8}$

At first glance, $L M$ seems to affirm the rights of the affected women. Moving beyond the narrow context of involuntary sterilisation, this judgment may be

Camilla Pickles. LLB, LLM, LLD (UP). British Academy Postdoctoral Research Fellow, Department of Law, University of Oxford. Research Fellow, South African Institute for Advanced Constitutional, Public, Human Rights and International Law (SAIFAC), University of Johannesburg, South Africa. E-mail: camilla.pickles@gmail.com.

Government of the Republic of Namibia v LM [2014] NASC 19 (hereafter LM case). $L M$ case paras 107-108, 110 .

$L M$ case para 3. Unfortunately, the court did not make an explicit declaration that the women's rights were violated as a result of being involuntarily sterilised.

Badul and Strode 2013 AHRLJ 216.

Badul and Strode 2013 AHRLJ 223.

Badul and Strode 2013 AHRLJ 223.

See Kangaunde and Tucker date unknown http://www.womenslinkworldwide.org/files/ gjo_summary_caseLMandOthersvNamibia_en.pdf.

Nair 2010 Harv Hum Rts $\mathrm{J} 231$. 
the first of its kind in southern Africa to consider women's medical decisionmaking powers during childbirth. The doctrine of informed consent ${ }^{9}$ is unquestionably applicable to all areas of medical treatment, but how the doctrine applies to the specificities of different areas of medical treatment is still being determined, and childbirth is one of those untouched areas. From this perspective, the $L M$ case could be described as ground-breaking because Namibia's highest court has confirmed that women have the final say regarding their non-emergency treatment during childbirth, irrespective of what healthcare providers determine to be in their best interests. ${ }^{10}$ However, I argue that worrying facets of the court's reasoning have been overlooked and this oversight may lie in the fact that the sterilisations were found to be unlawful and the affected women could proceed with their damages claim.

The purpose of this article is to move beyond the successful claim for damages and expose the harmful precedent that the $L M$ case sets in the context of women's rights during childbirth. First the article will look at what the court decided and how it came to reach that decision, in terms of the evidence it accepted and the authority it relied on. The article then "sounds the alarm" in three respects: It highlights some missing links within the court's reasoning; it reveals the court's harmful gender stereotyping of women during childbirth by portraying them as incompetent ${ }^{11}$ decision-makers at this time; and it contemplates some of the harmful ripple effects we should expect if the reasoning in the $L M$ case is applied to the context of childbirth more generally. The article goes on to explore why the $L M$ case is a South African issue and I argue that litigators and judicial officers in South Africa should guard against the reasoning in the $L M$ case because of its flawed reasoning.

$9 \quad$ According to Van Oosten there is no valid consent unless the patient knows and appreciates what he or she is consenting to. Knowledge and appreciation can only be achieved if the attending healthcare provider furnishes him or her with the appropriate knowledge. Appropriate and adequate knowledge about the proposed treatment becomes a requisite of knowledge and appreciation and thus a requisite of lawful consent. This places a legal duty on healthcare providers to impart necessary knowledge so as to enable a patient to make a decision concerning his or her treatment. The doctrine of informed consent protects and promotes patient autonomy and the rights to bodily and psychological integrity. See Van Oosten Doctrine of Informed Consent 447-448. See para 2 below for a more detailed discussion.

10 The court emphasised that its position regarding patients having a final say over treatment does not extend to emergency medical treatment; see $L M$ case para 106.

11 Incapacity and incompetence and capacity and competence are used interchangeably in this article. Carstens and Pearmain Foundational Principles 879 explain that "capacity ... refers to competence which refers to the functional ability to meet the demands of specific decision-making situations". 


\section{Government of the Republic of Namibia $v$ LM}

Three women living with HIV were sterilised after undergoing caesarean sections in public healthcare facilities. ${ }^{12}$ The women instituted civil action against the Namibian state, arguing that their sterilisations were unlawful because the procedures were performed without their informed consent. ${ }^{13}$ The High Court of Namibia found in favour of the three women. ${ }^{14}$ It held that the women did not provide their informed consent for the sterilisation procedures and the sterilisations were therefore unlawful. ${ }^{15}$ The state appealed to the Supreme Court of Namibia.

The Supreme Court of Namibia considered the circumstances surrounding the sterilisation of the three women. It recognised that the women had not gone to hospital for the purpose of being sterilised but to give birth to their babies, that signed consent was obtained while the women were in labour or when being taken to theatre for the purpose of performing caesarean sections, and that there was no documentation of the nature of the information provided when the women's signatures were acquired so as to ensure that their consent was informed. ${ }^{16}$ The court also turned to South African case law, Christian Lawyers Association v Minister of Health ${ }^{17}$ (hereafter Christian Lawyers Association case) and Castell v De Greef, ${ }^{18}$ (hereafter Castell case) for direction regarding the notion of informed consent and the important role it plays in relation to protecting patient autonomy while accessing healthcare.

$12 \quad L M$ case para 1.

13 The women also instituted a second claim arguing that their sterilisations were a result of them being HIV positive, and that their sterilisations thus constituted a wrongful and an unlawful practise of "impermissible discrimination". However, both the High Court and Supreme Court rejected this claim and as a result thereof this issue will not be considered in this article. For a critique of the court's finding in relation to the alleged discriminatory practice, see Badul and Strode 2013 AHRLJ 224-227; Patel 2017 Public Health Rev 15.

$14 \quad L M v$ Government of the Republic of Namibia [2012] NAHC 211 (hereafter LMHC case).

$15 L M H C$ case para 80.

$16 \quad L M$ case paras 100-102.

17 Christian Lawyers Association v Minister of Health 20051 SA 509 (T) (hereafter Christian Lawyers Association case). The Christian Lawyers Association case confirms that girls under the age of 18 years' have the right to decide to terminate their pregnancies in terms of the Choice on Termination of Pregnancy Act 92 of 1996 if they have the required capacity to provide informed consent.

18 Castell v De Greef 19944 SA 408 (C) (hereafter Castell case). The Castell case rejects medical paternalism and provides that the right to self-determination places an obligation on healthcare providers to obtain a patient's informed consent before providing treatment. 
In the Christian Lawyers Association case, the then Transvaal Provincial Division confirmed that informed consent

forms the basis of the doctrine of volenti non fit injuria that justifies conduct that would otherwise have constituted a delict or crime if it took place without the victim's informed consent. ${ }^{19}$

In the context of medical treatment, treatment will constitute a violation of a patient's right to privacy and personal integrity if it is provided without the patient's informed consent. ${ }^{20}$ Adding to this, informed consent was found to rest on three pillars: knowledge, appreciation and consent. ${ }^{21}$ "Knowledge" concerns full knowledge of the nature and extent of the risk associated with the treatment. 22 "Appreciation" means that the patient should comprehend and understand the nature and extent of the harm or risk. ${ }^{23}$ "Consent" requires that the patient should subjectively provide comprehensive consent, meaning that consent must be in relation to the entire course of treatment, including its consequences. ${ }^{24}$

The Supreme Court of Namibia accepted that in order for the patient's consent to be valid, the patient must have the capacity to consent. ${ }^{25}$ According to the Christian Lawyers Association case, "capacity to consent" refers to the intellectual and emotional ability of the patient to comprehend and understand the nature of any proposed treatment and the consequences thereof. ${ }^{26}$ The Supreme Court of Namibia interpreted this as suggesting that

it is crucial for us to determine whether the respondents had the intellectual and emotional capacity to give their informed consent in the light of the peculiar circumstances in which they found themselves when signing the consent forms. ${ }^{27}$

The court then accepted that the women's states of mind at the time of their signing the sterilisation consent forms, were affected by their labour pains and

Christian Lawyers Association case 515D.

Christian Lawyers Association case 515D-E.

Christian Lawyers Association case 515F.

Christian Lawyers Association case $515 \mathrm{H}$.

Christian Lawyers Association case $515 \mathrm{H}$.

Christian Lawyers Association case 516A.

LM case para 99.

Christian Lawyers Association case 516B.

$L M$ case para 100. It is noteworthy that the Christian Lawyers Association case did not consider the girl's capacity "in the light of particular circumstances" or the impact circumstances may have on her ability to make a decision. The court was primarily concerned with the emotional and intellectual maturity of girls to make abortion-related decisions. 
certain medical complications which necessitated urgent caesarean sections. $^{28}$

After noting that some of the healthcare providers testified that sterilisation was the best option available to the women concerned, ${ }^{29}$ the court turned to the Castell case for direction in relation the position of medical paternalism ${ }^{30}$ in contemporary societies. In the Castell case the court accepted that medical paternalism is based on outdated patriarchal attitudes and, in the context of medical treatment, the notion of patient autonomy conforms to human rights and individual freedom. ${ }^{31}$ Fundamental to patient autonomy is the principle of self-determination, which means that the patient decides whether to consent to, or refuse, medical treatment. ${ }^{32}$

The Supreme Court found that the doctrine of informed consent recognises that the patient has the final say, and given that sterilisation procedures are not emergency procedures, sufficient time should be allocated for informed and considered decision-making. ${ }^{33}$

The court applied the principles extracted from the case law to the circumstances of the women's sterilisations and found that the women had not given their informed consent. Despite the fact that most of the $L M$ case is dedicated to evidence that suggests that the women were not given sufficient information about sterilisation so as to be able to provide valid, informed consent, the court narrowly focussed on the women's capacity, being their emotional and intellectual ability, to comprehend the information being given at the time. The court's position on capacity during labour is as follows: ${ }^{34}$

The consent obtained was invalidated by the respondents' lack of capacity to give informed consent in light of the history of how the decision to sterilise them was arrived at and the circumstances under which the respondents' consent was obtained. It was merely written rather than informed consent. ... The important factor which must be kept in mind at all times is whether the woman has the capacity to give her consent for sterilisation at the time she is requested to sign

$28 \quad L M$ case para 102.

$29 \quad L M$ case paras 103, 104.

30 Tan explains that medical paternalism concerns the healthcare provider's "prerogative to act on his or her own best judgment for the patient" and that maximum patient benefit can only be achieved when the attending healthcare provider makes the final decision for the patient. Under medical paternalism, the focus is on health outcomes rather than the patient's needs and rights. See Tan 2002 Singapore Med J 148.

31 Castell case $422 \mathrm{H}$. The court quotes from Van Oosten Doctrine of Informed Consent.

32 Castell case $422 \mathrm{H}-\mathrm{I}$.

33 LM case para 107. It is worth noting that, in principle, contraceptive sterilisations are not classified as emergency procedures and therefore cannot be imposed as a therapeutic necessity. See WHO 2014 http://apps.who.int/iris/bitstream/10665/ 112848/1/9789241507325_eng.pdf?ua=1 14.

$34 \quad L M$ case para 108. 
consent forms. Therefore, it is not decisive what information was given to her during antenatal care classes or at the moment she signed the consent form if she is not capable of fully comprehending the information or making a decision without any undue influence caused by the pain she is experiencing.

The court found that the consent provided was invalidated by the fact that none of the women had the capacity to provide informed consent.

\section{Sounding the alarm}

Some of the initial responses to it have been positive, but the $L M$ case essentially finds that women who experience labour pains lack the capacity to give informed consent, and this cannot and should not be overlooked. Even though the court made this finding in respect of the three women affected, it can have quite broad application because it uses labour pains to deny capacity, and labour pains are something that most women will face during childbirth. ${ }^{35}$ Further, this finding can also have far reaching implications for all women in childbirth. If labouring or birthing people do not have the capacity to give consent during labour, by implication they will not have the capacity to refuse consent or withdraw a prior refusal or consent either. Given the potentially extreme implications of this judgment, a critical analysis of the judgment and the court's process is necessary.

\subsection{Missing links}

The finding of the Supreme Court is rather startling given that the capacity of the women to provide informed consent was not raised as an issue. The issue was whether the information provided was sufficient to allow the women to make an informed decision regarding their sterilisation. ${ }^{36}$ The High Court accepted that seeking consent during the height of labour was inappropriate but the court ultimately found that the state had failed to discharge its onus to prove that the women had been provided with sufficient information to render their consent informed. ${ }^{37}$ The high court's finding did not rest on the capacity of the women but on the fact that there was no record of the information provided to the women when obtaining their signatures on the relevant consent forms. ${ }^{38}$

35 Given the highly medicalised process childbirth has become, obstetric interventions are the norm rather than the exception and the right to refuse treatment is a crucial right to protect when confronted with an interventionist environment. See Burrows 2012 Techné 31.

$L M H C$ case paras $68,70,73$. 
Going further, the approach of the Supreme Court towards capacity during childbirth does not resonate with the approach adopted in factually comparable involuntary sterilisation matters before international fora. The Committee on the Elimination of Discrimination against Women and the European Court of Human Rights have each heard cases regarding the involuntary sterilisations of women or girls who consented to their sterilisations while in labour or while in theatre for the purpose of childbirth by way of caesarean section. ${ }^{39}$ In these instances, the court or committee found that the sterilisations were a violation of a number of human rights, because the procedures were performed without informed consent in so far as the information provided was insufficient to render the women informed.

In the AS case the applicant presented at hospital in labour, feeling very dizzy, bleeding more heavily than average, and in a state of shock; and she signed her consent form while in theatre. ${ }^{40}$ In this instance the committee focused on the obligation to provide timely and comprehensive information and counselling regarding sterilisation. ${ }^{41}$ It did not take the position that the applicant's childbirth experiences (pain and complications) removed her capacity to provide consent.

The $V C$ case is the second factually similar case. Here, the applicant attended hospital after the onset of labour and the issue of consent for sterilisation was raised by attending healthcare providers when the applicant was in the last stages of labour. ${ }^{42}$ Even though the applicant was on the verge of giving birth and was recognised to be in extreme pain, ${ }^{43}$ the European Court of Human Rights found her to be a mentally competent adult patient whose informed consent had to be obtained prior to the performance of a non-emergency medical procedure. ${ }^{44}$ Having regard to the applicant's medical record, the court found that the applicant had not been fully informed about her health status, the proposed sterilisation procedure or possible treatment alternatives. ${ }^{45}$ Further, the action of asking for consent after the applicant had been in labour for hours and just before the birth denied the applicant the time necessary to consider all the relevant issues and to discuss the matter with her partner. ${ }^{46}$

\footnotetext{
39 AS v Hungary Com No 42004 (CEDAW C/36/D/4/2004, 29 August 2009) (hereafter AS case); VC v Slovakia App No 18968/07 (ECtHR, 8 November 2011) (hereafter VC case). AS case para 2.2. AS case para 11.3. VC case paras 12, 15 $V C$ case para 15. $V C$ case para 110. VC case para 112. VC case para 112.
} 
In each of the above cases the various applicants were experiencing labour pains and facing health complications during labour or childbirth, and the court or committee never questioned the capacity of the applicants to provide informed consent on these grounds. ${ }^{47}$

The approach adopted by international fora is in line with the generally accepted and applied presumption that an adult is presumed to be competent unless there is evidence indicating otherwise. This presumption can be found in the common law, legislation, case law and guidelines for healthcare professionals. ${ }^{48}$ Thus, the approach of the international community is in line with medical practice. In this regard, Appelbaum explains that when assessing the competency of a patient to provide consent

examiners should first ensure that patients have been given the information that is relevant to making an informed decision about their treatment. ${ }^{49}$

This suggests that capacity cannot be questioned without first exploring the information provided to the patient. When it becomes apparent that capacity is in question because the patient is unable to understand and weigh the information provided, the patient should be individually assessed by the treating healthcare provider, psychiatrist or psychologist, and that assessment should serve as evidence regarding capacity at the relevant time. ${ }^{50}$

$47 \quad$ NB v Slovakia App No 29518/10 (ECtHR, 12 June 2012) is one exception. The applicant was experiencing labour pains but she was sedated in preparation for childbirth by way of caesarean section, and then asked to sign her sterilisation consent form. In this instance, the ECtHR accepted that the applicant lacked the capacity to provide consent because of the effects of sedation and not on the basis of labour pains or childbirthrelated complications.

48 See Heaton South African Law of Persons 36; Himonga "Persons and Family" 146-147. A manifestation of this presumption can be found in South African criminal law and law of succession case law: see S v Els 19931 SACR 723 (O); Geldenhuys v Borman 1990 1 SA 161 (E). For the Namibian context, see $S$ v Hangue 2016 JDR $0044(\mathrm{NmS}) ; S v$ Rickerts 2016 JDR $0442(\mathrm{Nm})$. Also see the HPCSA 2008 http://www.hpcsa.co.za/downloads/conduct_ethics/rules/generic_ethical_rules/booklet _9_informed_consent.pdf 7 . An example of a legislative expression of this presumption can be found in s 1(2) of the English Mental Capacity Act, 2005; it states that a "person must be assumed to have capacity unless it is established that he [or she] lacks capacity". In the context of forced obstetric interventions on pregnant women in England, see Re T [1992] EWCA Civ 18; Re MB [1997] EWCA Civ 3093. See Donnelly 2007 JSIJ 141 for a more general application of the presumption of capacity in the United Kingdom and Skegg 2011 U Queensland LJ 165 for a critique of the presumption of capacity.

49 Appelbaum 2007 N Engl J Med 1837. Also see Brooks and Sullivan 2002 Int J Obstet Anesth 198.

$50 \quad$ See Ladd 1989 Hypatia 41; Cahill 1999 Nursing Ethics 499; Appelbaum 2007 N Engl J Med 1834; Nicholas and Nicholas 2010 TOG 30-31. 
Against this backdrop, it is necessary to consider what the Supreme Court relied on to reach the conclusion that the affected women lacked the capacity to provide informed consent. The judgment itself reveals that very little evidence was considered in relation to the impact of labour on the capacity to provide informed consent. The court accepted the expert evidence of one specialist gynaecologist and obstetrician, Dr Kimberg, according to whom: ${ }^{51}$

\begin{abstract}
[D]uring labour a woman might experience pain of such a level and intensity that she loses a sense of reality; she may stop thinking rationally. A woman may be aware only of the pain, and may 'grasp at straws' to be relieved of such discomfort. ... consent should not be obtained from women in circumstances when they are experiencing so much pain. According to him, many women in the height of labour say that they would not choose to experience the pain of childbirth again, yet many still return with a pregnancy the following year.
\end{abstract}

The court weighed Dr Kimberg's evidence against the evidence presented by the state's witnesses and found that the state's evidence did not challenge $\mathrm{Dr}$ Kimberg's position. ${ }^{52}$ On this basis, the court concluded that the women's consent was invalidated by the fact that they lacked the capacity to give informed consent

none of the respondents gave informed consent because they were in varying degrees of labour and may not have fully and rationally comprehended the consequences of giving consent for the sterilisation procedure. ${ }^{53}$

The Court gave preference to Dr Kimberg's evidence, which is far too generalised and could be described as a one-sided description of the impact of labour pain on women and on their capacities when experiencing that pain. The evidence implies that all women have the same response to labour pain and certain complications during childbirth. The court disregarded the evidence of the nurses who attended the applicants during their labour. Snippets of the nurses' testimonies suggest that a nuanced and individualised approach should be adopted when considering the capacity of the affected women to give their consent while experiencing labour pain. For example, a nurse testified that labour pains "come and go", that there are different types of labour pains during the labour process, and that she would explain procedures and obtain consent in between contractions. ${ }^{54}$ Another nurse testified that she would not speak to patients while they were experiencing labour pains, and that she knew when contractions were severe and when they were not. ${ }^{55}$ An attending medical officer in the Department of Obstetrics and

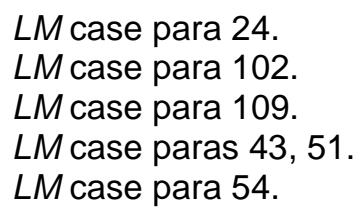


Gynaecology, where one of the applicants was sterilised, testified that pain was a "subjective matter" and

all women are in pain during labour but that this consideration alone did not render them incapable of giving their informed consent. ${ }^{56}$

There was no evidence, at least as recognised in the judgment, which meaningfully sets out the individual circumstances of the women or their individual responses to labour pains. That is, the women's voices in relation to their personally perceived ability to provide informed consent while in labour is notably absent from the judgment. ${ }^{57}$ All the women implicated are separate individuals and they may have perceptions and responses to circumstances different from those of other women as a result of their having different life experiences. ${ }^{58}$ Further, there was no appropriate expert evidence before the court, or at least none recognised in the judgment, which provided objective, professional assessments of the three women's mental states when consent was provided. ${ }^{59}$

In view of the existence of these gaps, it is difficult to accept that an obstetrician's general perceptions of women in labour should stand as evidence applicable to all three of the women. In effect, the court has given the force and authority of law to a generalised perception of labouring women without the foundation of objective evidence specific to each woman, or without relying on any established judicial precedent. From this perspective, it can be

$56 \quad L M$ case paras $61,63$.

57 Two applicants reportedly had different responses to pain, the judgment briefly alludes to the fact that the second respondent testified that she was in too much pain to inform her doctor that she did not want to be sterilised and that the third respondent wanted her pain to be eased, see $L M$ case paras 17, 20. However, needing pain relief or feeling unable to speak at a certain point during labour does not indicate a lack of capacity. According to the Christian Lawyers Association case 516B, the test for capacity concerns the emotional and intellectual ability to form a particular will.

58 For example, all women had different experiences with previous pregnancies and childbirths. The first applicant was 26 at the time, it was her third pregnancy and the two previous childbirths were vaginal births, see $L M H C$ case para 20. The second respondent's age is unknown, but she previously gave birth to three children, two of which were via caesarean-section procedures, see $L M H C$ case para 22. The third respondent was 46 years old at the time of the incident and she was giving birth to her eighth child, six of her deliveries were vaginal births, see $L M H C$ case para 23. According to Ladd, these experiences may change women's responses to pain during labour, see Ladd 1989 Hypatia 41. Going further, there is scholarship which suggests that some women have positive experiences in relation to labour pain and describe it as empowering, fulfilling and creative, see generally Cohen Shabot 2017 Eur J Women Stud 128. This scholarship emphasises the need for an individualised approach to women in labour.

59 Appropriate expert evidence would be evidence provided by a psychiatrist or psychologist, not a gynaecologist. See generally Donnelly 2007 JSIJ 141. 
argued that the court relied on and perpetuated a particular stereotype of women in labour.

\subsection{Stereotyping women}

\section{A stereotype can be defined as a}

generalized view or preconception of attributes or characteristics possessed by ... members of a particular group, such as women. Irrespective of individuals' personalities, capacities or qualities, those perceived as members of the groups are regarded as possessing characteristics that are typical of that group. ${ }^{60}$

Cook and Cusack explain that a

finding that a law, policy or practice stereotypes women, hinges on the existence of a generalised view or preconception concerning the attributes or characteristics that are possessed by women

without having regard to the individuality of the people concerned. ${ }^{61}$ Further, the authors explain that there are several indicators that help reveal circumstances when a stereotype is being applied. These include selective interpretation or an extreme evaluation or judgment based on limited evidence. $^{62}$

Cusack and Cook identify three stereotypes of women that emerge in the context of female reproductive healthcare. ${ }^{63}$ Women are stereotyped as being primarily mothers and this stereotype prescribes that women should prioritise childbearing and childrearing over all other possible roles. ${ }^{64}$ Women are stereotyped as being weak and vulnerable and this infers that women are in need of third-party protection. ${ }^{65}$ Women are stereotyped as incompetent decision-makers, which implies that they are irrational, that they lack the capacity for agency, that they are incapable of making difficult decisions, or that they are prone to regretting decisions made. ${ }^{66} \mathrm{It}$ is the final stereotype,

60 See Cook, Cusack and Dickens 2010 Int J Gynaecol Obstet 255. See also Gillmor 2000 Int J Childbirth Educ 8; Cusack and Cook 2009 JCRSJ 49-55.

$61 \quad$ Cook and Cusack Gender Stereotyping 45.

62 Cook and Cusack Gender Stereotyping 47.

63 Cusack and Cook 2009 JCRSJ 55-56.

64 Cusack and Cook 2009 JCRSJ 55.

Cusack and Cook 2009 JCRSJ 55, 66. Protection is afforded via restrictive laws, practices or policies which work to limit access to healthcare services such as certain late-term abortion procedures or by requiring attending healthcare providers to protectively approve women's decisions to undergo abortions. See Halliday Autonomy and Pregnancy 52; Cook, Cusack and Dickens 2010 Int J Gynaecol Obstet 256; Bonnington et al Contraception 443.

Cusack and Cook 2009 JCRSJ 56; Cook, Cusack and Dickens 2010 Int J Gynaecol Obstet 256. For instance, in the context of court-ordered obstetric interventions, women have been found to be irrational for refusing medically-advised interventions, and 
that women are incompetent decision-makers, which is relevant for the purpose of this article's assessment of the $L M$ case.

Stereotyping women as incompetent decision-makers is particularly prevalent in the context of medical decision-making during childbirth in so far as it is assumed that women lack the capacity to make medical decisions as a result of their experiencing labour pains. Examples of how this stereotype plays out in women's lives can be found in case law, obstetric practice and research, and scholarly publications.

In Norfolk and Norwich Healthcare (NHS) Trust $v W^{67}$ (hereafter Norfolk), W was on the verge of giving birth but was in a state of arrested labour, and she refused to undergo medically-advised obstetric interventions to assist her during childbirth. Her healthcare provider sought an order authorising the use of forceps or caesarean section surgery, despite her refusals. The court found that W

lacked the mental competence to make a decision about the treatment that was proposed because she was incapable of weighing up the considerations that were involved. She was called upon to make that decision at a time of acute emotional stress and physical pain in the ordinary course of labour. ${ }^{68}$

The same approach was followed in the Rochdale Healthcare case, ${ }^{69}$ where the court found that $\mathrm{C}$ was rendered incapable of making a valid decision regarding the birth of her child because of the pain and emotional stress associated with her labour. Both cases found that there was no expert evidence to support a finding that $\mathrm{C}$ and $\mathrm{W}$ were incapable of making medical decisions.

If the courts in the above matters did not have evidence establishing that the women lacked capacity, one must ask what the courts relied on to reach such

"irrationally" refusing treatment was taken to indicate a lack of capacity; see Dickens and Cook 2015 Int J Gynaecol Obstet 107; Halliday Autonomy and Pregnancy 40-92. In Rochdale Healthcare (NHS) Trust v C [1997] 1 FCR 274 275G-H (hereafter Rochdale Healthcare case), in response to the patient's preference of death over experiencing another caesarean section, the court found: "[A] patient who could ... speak in terms which seemed to accept the inevitability of her own death, was not a patient who was able to properly weigh-up the considerations that arose so as to make any valid decision, about anything of even the most trivial kind, surely still less one which involved her own life." The court reached this decision despite the attending obstetrician being of the opinion that the patient was competent and no psychiatric evidence was provided to indicate otherwise. The court found that the patient lacked capacity to refuse consent and that performing a caesarean section would be in her best interests. Norfolk and Norwich Healthcare (NHS) Trust v W (1996) 34 BMLR 16 (hereafter Norfolk case).

$68 \quad$ Norfolk case 19

69 Rochdale Healthcare case 275G. 
extreme conclusions. In this regard Wei argues that the courts relied on a longstanding general assumption of women's incompetence during labour and childbirth. ${ }^{70}$ Ladd and Flanigan's scholarship on informed consent during labour highlights the pervasive belief held by healthcare providers that the emotional stress of pain impairs a labouring woman's cognitive and rational ability to understand and appreciate the information provided by attending healthcare providers. ${ }^{71}$ This assumption is "pervasive" to the extent that it has made its way into professional journal articles and published books, which advise healthcare providers to obtain consent for possible procedures prior to the onset of labour. ${ }^{72}$ For example, midwives have been advised that consent should be obtained during the antenatal period, since labour pain and anxiety "are likely to detract from the woman's ability to make informed choices". ${ }^{73}$

The assumption that labouring women lack capacity during labour and childbirth has clearly shaped how consent is obtained in obstetric practice. Frequently women are required to sign general consent forms upon their admission into hospital or prior to the onset of their labour for a range of procedures that may not be necessary at the time of admission. ${ }^{74}$ Furthermore, women are encouraged to complete and submit birth plans. ${ }^{75}$ These methods of obtaining consent reinforce the assumption that women lack the capacity to make medical decisions during labour and childbirth. ${ }^{76}$ Cahill argues: $: 77$

The implicit message is that, while women may be deemed competent at the time they complete the [birth] plan, at the onset of labour and delivery they will no longer be so.

Her interpretation is supported by reports of the refusal by attending healthcare providers to accede to a woman's change of mind regarding care or

$70 \quad$ Wei 2016 Legal Issues 89. Also see Cahill 1999 Nursing Ethics 499.

$71 \quad$ Ladd 1989 Hypatia 40-41; Flanigan 2016 Ethical Theory Moral Pract 228.

72 See those sources cited by Ladd 1989 Hypatia 37; Cahill 1999 Nursing Ethics 501.

73 As quoted in Cahill 1999 Nursing Ethics 501. This advice would not be problematic if it emphasised that midwives should approach each woman on an individual basis instead of advancing a blanket approach which presumes incapacity.

$74 \quad$ See Ladd 1989 Hypatia 37.

75 Lothian explains that a birth plan is a formal written plan drafted by pregnant women which expresses and clarifies their desires and expectations regarding care during childbirth. The plan helps women communicate with their healthcare providers. See Lothain 2006 JOGNN 296. Regarding encouraging women to complete birth plans, see Nicholas and Nicholas 2010 TOG 30. 
interventions during labour or childbirth in instances where a birth plan is in place. ${ }^{78}$

Medical research too is shaped by the assumption that women lack the capacity to provide informed consent during labour and childbirth. Reid et a/9 note the widely held concern that

\begin{abstract}
it is unclear whether women in labour are capable of giving fully informed consent for research as they need to be capable of rational decisions when provided with full and relevant information. The act of giving birth, including the influence of pain during labour, may significantly inhibit rational decision-making with respect to patient involvement.
\end{abstract}

Reid et al reveal a preference for obtaining consent prior to the onset of labour, and one respondent in their study emphasised that his or her committee would insist on prospective consent in all cases. ${ }^{80}$ This respondent's position was based on concerns regarding the capacity of women to consent during labour. ${ }^{81}$

Relying on a stereotype may not in itself necessarily be problematic. In fact, Cook, Cusack and Dickens accept that generalisations of highly complex issues can be helpful and the use of stereotypes can offer a measure of predictability and security. ${ }^{82}$ Nevertheless, the authors caution that stereotyping can be harmful when stereotypes, which are based on flawed perceptions or ill-founded presumptions, are applied in ways that result in exclusion and disadvantage.

Women are frequently disadvantaged and harmed by the application and enforcement of certain stereotypes. ${ }^{83}$ Stereotypes that harm, disadvantage and unlawfully discriminate ${ }^{84}$ against women are those that confine women to

Brooks and Sullivan 2002 Int J Obstet Anesth 200; Thornton and Moore 1995 Int J Obstet Anesth.

Reid et al 2011 Aust N Z J Obstet Gynaecol 485.

Reid et al 2011 Aust N Z J Obstet Gynaecol 487.

Reid et al 2011 Aust N Z J Obstet Gynaecol 487. As a consequence of this approach, labouring women are routinely excluded from clinical trials and this hampers the development of improved clinical care during childbirth.

See Cook, Cusack and Dickens 2010 Int J Gynaecol Obstet 256. Also see Cusack and Cook 2009 JCRSJ 51.

Cook, Cusack and Dickens 2010 Int J Gynaecol Obstet 255.

Cook, Cusack and Dickens explain that stereotyping may be unlawful because the "[d]isadvantage that individuals suffer due to treatment different from that afforded others from whom they are not materially different constitutes discrimination. Women are materially different from men due to physique and reproductive functions, but not in their capacity for moral reflection or understanding of information, or, for instance, their right to self-determination. Accordingly, when men can receive health services without government or state intervention, but women have to satisfy stereotypical legislated, 
certain gendered roles, prescribe what women can or cannot do, and ignore women's individual characters, abilities, needs, desires and circumstances in ways that deny them their rights. ${ }^{85}$

According to Cook, Cusack and Dickens, stereotyping women as incompetent decision-makers within the realms of reproductive care has far-reaching consequences because the stereotype is used to deny women reproductive self-determination and moral agency, it infantilises them and justifies surrogate decision-making. ${ }^{86}$ Going further, the harms associated with the blanket assumption of incapacity during childbirth must be dismantled because this approach cannot be justified. It is now being revealed that this stereotype lacks an evidential foundation.

During the 1970s and 1980s empirical research suggested that emotional stress and pain had the effect of impairing a person's ability to understand and appreciate information, thus offering a measure of support for the generalisation that women experiencing labour pains lack the capacity to provide informed consent. ${ }^{87}$ However, recent empirical research debunks these earlier findings and find that a generalised view that a person will lack the capacity to consent as a result of pain can no longer be supported. ${ }^{88}$ Casarett, Karlawish and Hirschman find that there is no relationship between pain and decision-making capacity. ${ }^{89}$ Instead, they find that factors such as age, education and literacy have the potential to undermine decisional capacity

customary or other criteria inapplicable to men, women suffer discrimination, and this is liable to be unlawful." See Cook, Cusack and Dickens 2010 Int J Gynaecol Obstet 257. Cook, Cusack and Dickens 2010 Int J Gynaecol Obstet 255; Cusack and Cook 2009 JCRSJ 51-52. For instance, the stereotype that women are primarily mothers is used to deny many women access to emergency contraception or family planning information, and prevents access to safe and lawful termination-of-pregnancy services. See Cusack and Cook 2009 JCRSJ 56-65. This stereotype is also found in England's forced caesarean-section judgments where obstetric care is imposed on the basis that giving birth to a live baby is in the woman's best interests, see Norfolk case 19; Bolton Hospitals NHS Trust v O [2003] 1 FLR 824 827; Re L (1996) 35 BMLR 44; Tameside \& Glossop Acute Services Trust v CH [1996] 1 FLR 762 773. Also, in the context stereotyping women as vulnerable and thus in need of protection from difficult and "regrettable" decisions, Cook, Cusack and Dickens 2010 Int J Gynaecol Obstet 255 demonstrate how the United States Supreme Court judges, in Gonzales v Carhart 550 US 124 (2007) relied on this stereotype to justify upholding the Partial-Birth Abortion Ban Act, 2003. This Act denies women access to a particular late-term abortion procedure which may be medically indicated at times. For a further critique of this approach, see Siegel 2008 Duke LJ 1641.

87 See the discussion of this evidence in Ladd 1989 Hypatia 40-41. 
in so far as these factors may impact on the ability of patients to understand information provided. 90

While Casarett, Karlawish and Hirschman's research concerns patients living with cancer, the same results emanate from studies examining labouring women's ability to provide informed consent for epidural analgesia. ${ }^{91}$ This empirical research is particularly helpful because informed consent must be provided for epidural analgesia ${ }^{92}$ and in these studies the participants provided consent after the onset of labour and while they were experiencing labour pains, presumably when they could no longer endure the pain associated with labour.

Gerancher et al demonstrate that women are able to engage in the informed consent process despite being in active labour and this finding is aligned with the labouring women's self-perception that they were able to give informed consent. ${ }^{93}$ Jackson et al find that the ability to understand risks is not affected by labour pain, the duration of labour pain, anxiety, or the desire for an epidural, and they conclude that

labouring patients are as able to give informed consent as are other members of our patient population. ${ }^{94}$

In fact, Jackson et al argue that the informed consent process can be truly complete only once women are in labour and fully experiencing labour and childbirth:

It is arguable that only during labour when the severity of pain has been realized and the consequence of continuing without intervention becomes clear, can the informed consent process be complete. ${ }^{95}$

Also, Gerancher et al suggest that

labouring women may be more likely than patients with illness or elderly volunteers to be attentive to the consent process because they feel empowered to make decisions

Casarett, Karlawish and Hirschman 2003 J Pain Symptom Manage 621. Gerancher et al 2000 Int J Obstet Anesth 168; Jackson et al 2000 Can J Anesth 1068. Broaddus and Chandrasekhar 2011 Anesth Analg 912 explain that these studies test whether women could recall the information provided to them while they were in labour. The authors explain that methodology effectively assesses the measure of absorption and understanding of information. Jackson et al 2000 Can J Anesth 1069.

Gerancher et al 2000 Int J Obstet Anesth 168. Jackson et al 2000 Can J Anesth 1068. Jackson et al 2000 Can J Anesth 1071. 
and many pregnant women may possess baseline medical knowledge relevant to labour and childbirth, thus rendering informed decision-making realisable during labour. ${ }^{96}$ Flanigan $^{97}$ and Ladd $^{98}$ reveal that baseline knowledge may originate from antenatal care and/or from previous pregnancies and childbirths. ${ }^{99}$

The findings considered here do not support the assertion that all women who experience labour pains will always enjoy full capacity to provide informed consent. Gerancher et al and Jackson et al also identified a small group of women as being unable to provide informed consent because of the pain of labour. 100 However, the findings emphasise that current empirical research does not support a blanket presumption of the incapacity of labouring women. Therefore, the stereotype that women are incompetent medical decisionmakers during childbirth lacks an evidentiary foundation and cannot be relied on to justify denying labouring women their agency and rights to reproductive self-determination and dignity, among other rights.

\subsection{Harms of Government of the Republic of Namibia v LM}

It is clear that the $L M$ judgment relies on and perpetuates a stereotype proffered by a healthcare provider, Dr Kimberg. The labouring women were found to be incompetent decision-makers on the basis of experiencing labour pains during childbirth. This is a generalised view of women in labour and the court's position is based on extremely limited evidence.

While stereotyping and relying on stereotypes are not inherently problematic, in this instance, stereotyping may be extremely harmful. At first glance the potential harm is difficult to appreciate because the affected women's claims against the state were successful. However, what makes the court's position problematic is the fact that it portrays all women who share characteristics comparable to those of the three women in the $L M$ case as lacking the capacity

$96 \quad$ Jackson et al 2000 Can J Anesth 1072.

$97 \quad$ Flanigan 2016 Ethical Theory Moral Pract 230.

$98 \quad$ Ladd 1989 Hypatia 41.

99 However, these arguments assume that access to antenatal care is universal, that all relevant information will be provided, and that women have laboured and previously experienced childbirth in a hospital environment. It is necessary to explore how baseline knowledge can be acquired through traditional knowledge and whether those relying on this form of knowledge render them less capable of providing informed consent in a highly medicalised birth setting.

100 See Gerancher et al 2000 Int J Obstet Anesth 170; Jackson et al 2000 Can J Anesth 1071 respectively. 
to provide consent as a result of their experiencing labour pains. ${ }^{101}$ Not only is this position not supported by emerging empirical research (as discussed above) but it also denies women in childbirth their reproductive rights. These rights include the rights to equality, self-determination, dignity and bodily integrity, and the right to be free from violence within the context of reproductive healthcare. ${ }^{102}$ Stereotyping women as incompetent decisionsmakers lays the foundation for infantilising them, enables surrogate decision making, and effectively dismantles patient autonomy and all that it protects.

Maintaining the right to self-determination during childbirth is important for a number of reasons. There is an increase in the prevalence of routine clinical and technological management of childbirth ${ }^{103}$ such as foetal monitoring, episiotomies and labour induction, and framing an intervention as "routine" causes women to be burdened with the responsibility of refusing interventions rather than burdening healthcare professionals with the obligation to obtain valid, informed consent. ${ }^{104}$ This approach pressurises or impairs women's autonomy, and presuming incapacity would exacerbate this worrying trend. Compounding this issue is the emerging discourse that a refusal to undergo treatment requires the possession of a higher degree of capacity because of the possible harmful consequences that may materialise in cases where an intervention does not occur. ${ }^{105}$ Also, women may change their minds during childbirth and may wish to withdraw either their consent or their prior refusal, ${ }^{106}$ and the right to do so will be denied in cases where women are presumed to lack the capacity to make informed decisions while experiencing labour pains during childbirth.

Going further, the $L M$ case is problematic because it characterises the issue of involuntary sterilisation as an inadequacy on part of the affected women.

101 See Cusack and Cook 2009 JCRSJ 74 regarding the ripple effect of applied stereotypes.

102 See ss 9, 10 and 12 of the Constitution of the Republic of South Africa, 1996 (hereafter Constitution).

103 This approach has links to the employment of "defensive medicine", see Johanson, Newburn and Macfarlane 2002 BMJ 892. Defensive medicine occurs when medical practitioners perform procedures to avoid exposure to malpractice litigation, see Sekhar and Vyas 2013 Ann Med Health Sci Res 295.

104 See generally Burrows 2012 Techné 36-38; Glennon "Regulation of Reproductive Decision-Making" 152-153. Glennon reveals how healthcare professionals, within the context of assisted reproduction, are able to influence patients' decision-making by making use of default rules which very few patients contest because of their default status.

105 Dickens and Cook 2015 Int J Gynaecol Obstet 105.

106 Withdrawal of consent or prior refusal is likely to happen because women are only truly informed once they are in the position to experience the process of childbirth, see Jackson et al 2000 Can J Anesth 1071. 
The sterilisations were found to be unlawful because of a flaw found within the three women: that each of them lacked the capacity to provide consent because of the pain of their labour. By adopting this approach, the court removed its focus from the healthcare professionals and their questionable practice of obtaining consent for non-therapeutic procedures during labour and childbirth. The flaw in this case does not lie with the women who are giving birth but with the healthcare professionals who obtain consent without providing adequate information and without providing adequate time for labouring patients to consider their reproductive health options. The sterilisations were involuntary and unlawful because the affected women were never provided with adequate information regarding sterilisation as a means of contraception. We cannot fault women's capacity to comprehend and understand information if they were never given the information to start with.

From this perspective it can be argued that the $L M$ case does not advance labouring patients' rights, nor does it promote or protect women's reproductive rights. Further, it does not encourage respect for reproductive choices because it creates an environment where a woman's choice will be denied if she attempts to exercise that choice while in the throes of labour. The reasoning in the judgment effectively lays the foundation for the violation of women's rights during childbirth. A judgment that advances patient autonomy, reproductive rights and respect for reproductive choices would have focussed on and clarified the healthcare profession's obligations in relation to the provision of the correct information for the purpose of contraceptive sterilisation and confirmed and applied labouring women's rights to self-determination and reproductive autonomy. Instead, the $L M$ case embeds into Namibian law the stereotype that labouring women are incompetent decision-makers while they are experiencing labour pains, and it sets a precedent which will be hard to overturn, given that this judgment comes from Namibia's highest court.

\section{Government of the Republic of Namibia $v$ LM as a South African concern}

In South Africa the scope of reproductive rights is still being determined, and to date the focus of legislation and litigation has been limited concerns relating to the avoidance of becoming a parent ${ }^{107}$ and surrogacy. ${ }^{108}$ As a result of this

\footnotetext{
107 See the Choice on Termination of Pregnancy Act 92 of 1996; Sterilisation Act 44 of 1998; Christian Lawyers Association of SA v Minister of Health 19984 SA 1113 (T); Christian Lawyers Association case.

108 See ch 19 of the Children's Act 38 of 2005; AB v Minister of Social Development 2016 2 SA 27 (GP); AB v Minister of Social Development 20173 SA 570 (CC).
} 
very narrow focus, South Africa has not fully explored how the Bill of Rights applies to people during childbirth. ${ }^{109}$ However, this is set to change.

Recently, reports have revealed that HIV-positive women living in South Africa have been sterilised without their informed consent. ${ }^{110}$ In these instances it has been argued that consent was invalid because it was not informed and was provided while the women were in the throes of labour or on the verge of giving birth by way of caesarean section. Litigation has commenced for some of the affected women. ${ }^{111}$ While this litigation is concerned with the lawfulness of the sterilisation procedures, it also opens the door to a consideration of the broader issue of reproductive rights in childbirth, and it is at this juncture that the $L M$ case and its potentially harmful effect becomes relevant to South Africa.

Aside from the fact that section $39(1)(c)$ of the Constitution permits the consideration of foreign law when interpreting the rights in the Bill of Rights, there are strong and exact indications that the $L M$ case may make its way into current litigation strategies against involuntary sterilisations in South Africa. The $L M$ case has been framed as advancing reproductive and patient rights, it is the first sub-Saharan African case of its kind which addresses an issue that impacts on women in South Africa, those supporting its outcome have roots in South Africa and are involved in the South African involuntary sterilisation investigations, ${ }^{112}$ and $L M$ relied on South African case law to reach its outcome.

At first glance the $L M$ case demonstrates the potential of South African abortion ${ }^{113}$ and medical negligence ${ }^{114}$ case law to advance reproductive rights and the rights of obstetric patients in relation to obtaining consent for elective procedures during childbirth. However, the reasoning in the $L M$ case contradicts and possibly erodes the very principles advanced in the Castell and Christian Lawyers Association cases.

109 This concern is not unique to South Africa. To date, there is no international or regional instrument which establishes or demonstrates how human rights apply to the context of childbirth. See Murphy 2009 Ave Maria L Rev 443; Spence 2012 Cardozo JL \& Gender 101 for scholarship calling for increased attention to this issue.

110 See Strode, Mthembu and Essack 2012 RHM 61; Essack and Strode 2012 Agenda 24.

111 According to Strode, one matter was settled out of court and two or three matters are before the high courts, e-mail from Ann Strode on 11 January 2016.

112 See Badul and Strode 2013 AHRLJ 215. At the time of writing, Badul is the Director of the University of KwaZulu Natal's Law Clinic and Strode is a Senior Lecturer at the same institution. Their co-authored article suggests a way forward in relation to litigating against involuntary sterilisation after the $L M$ case.

113 Christian Lawyers Association case.

114 Castell case. 
The Castell case found that informed consent is based on the right to selfdetermination and patient autonomy. These rights oblige doctors to take a patient-orientated approach when determining what information should be provided for the purpose of obtaining valid consent, and it is for the patient to determine whether to undergo any proposed treatment. ${ }^{115}$ Relying on Castell, the Christian Lawyers Association case found that the first leg of the informed consent process is the provision of relevant information to the patient. The second leg concerns the patient's ability to appreciate and understand the information provided. This implies that one cannot claim that a patient lacks the ability to understand and comprehend the nature of a proposed treatment without first offering the information to the patient. ${ }^{116}$ The $L M$ case not only sidestepped the issue of the obligations of a healthcare provider in relation to providing adequate and appropriate information, but it also put the horse before the cart in so far as it attacked a woman's capacity to understand information without having regard to the information that should have been provided. On this point, $L M$ concludes: ${ }^{117}$

Therefore, it is not decisive what information was given to her during antenatal classes or at the moment she signed the consent form if she is not capable of fully comprehending the information.

The $L M$ case paves the way for dismantling birthing women's rights to information, and in doing so it diminishes women's rights to self-determination and their autonomy as patients. Further, the application of the $L M$ case in South African litigation strategies may inadvertently open the door to medical paternalism, which is the very issue that the Castel and Christian Lawyers Association cases stand against.

More generally, the $L M$ case is problematic within a South African setting because South Africa itself is struggling to develop jurisprudence that is removed from stereotypes relating to gender, gender roles, female vulnerability and sexuality. According to Albertyn, the Constitutional Court is yet to meaningfully give effect to the right to equality in a way that transforms and dismantles gender stereotypes, norms and structures that create and

\footnotetext{
115 Castell case 420G-J, 426E.

116 This approach is in line with the approach adopted in relation to the clinical assessment for capacity. The clinical assessment approach accepts that capacity is "function specific" in that a patient may have capacity to consent for one medical intervention but lack the capacity to consent to another, and it is only through the assessment of a patient's ability to comprehend and understand the information being conveyed that capacity can be established, if in doubt. See Appelbaum 2007 N Engl J Med 1837; Nicholas and Nicholas 2010 TOG 30; Hope 2005 Medicine 5.

$117 \quad L M$ case para 108.
} 
perpetuate certain inequalities in society. ${ }^{118}$ In this respect, Albertyn distinguishes between equality judgments that increased inclusion and those that result in transformation. ${ }^{119}$ She explains that an inclusive approach to equality

broadens the umbrella of social recognition, but does not address the structural conditions that create and perpetuate systemic inequalities. ${ }^{120}$

An approach that secures transformation should work to dismantle power relations, stereotypes and dominant norms that supress, subordinate and maintain inequality. ${ }^{121}$

After analysing four Constitutional Court equality judgments, ${ }^{122}$ Albertyn effectively demonstrates that the Constitutional Court has been unable to move beyond dominant norms and existing stereotypes and restructure the systems that create the privileged positions upon which inequality thrives. ${ }^{123}$ She argues that the transformative potential of the judgments is hindered in part by their reliance on and application of stereotypes about gender and sexuality. ${ }^{124}$ For instance, in the Hugo case ${ }^{125}$ the Constitutional Court failed to meaningfully recognise that men may also be single parents with childcare responsibilities comparable to those of some women. She argues that the court was unable to do so because it focussed on the stereotype that women fill the role of mother and primary care-provider, and thereby entrenched stereotypical gender roles. ${ }^{126}$ In the Masiya case ${ }^{127}$ the court's reliance on the stereotype that women are vulnerable and need protection contributed towards

\footnotetext{
118 Albertyn 2007 SAJHR 253.

119 Albertyn 2007 SAJHR 256.

120 Albertyn 2007 SAJHR 256.

121 Albertyn 2007 SAJHR 256.

122 President of the Republic of Republic of South Africa v Hugo 19974 SA 1 (CC) (hereafter Hugo case); S v Jordan 20026 SA 642 (CC); Volks v Robinson 20055 BCLR 446 (CC); Masiya v Director of Public Prosecutions 20075 SA 30 (CC) (hereafter Masiya case).

123 Albertyn 2007 SAJHR 261-270. This is not to say that parties were left without remedies but that the remedies were ineffective in facilitating transformation. For instance, with reference to cases concerning the right to equality and sexual orientation, the court's remedial approach is to include gay and lesbian populations into existing institutions and norms rather than dismantling those norms and institutions that created the framework for exclusion.

124 For a further discussion, see Albertyn 2007 SAJHR 261-264.

125 In the Hugo case the Constitutional Court found that granting special remission of sentences to only mothers and not fathers with minor children under age of 12 years did not unfairly discriminated against single fathers.

126 Albertyn 2007 SAJHR 261-264.

127 In the Masiya case the Constitutional Court developed the common law definition of rape to include anal penetration of a woman but did not go so far as to include unconsented anal penetration of men.
} 
a finding that the crime of rape should not be extended to include the rape of men. Albertyn stresses the concern that South African courts are susceptible to the hidden influences of stereotypes and that they maintain a position of conformity to dominant norms and privileging structures which institutionalises stereotypes rather than challenges or dismantles them.

The general support and positive reception of the $L M$ case and the environment of the persistent application of stereotypes by the South African judiciary makes this case particularly worrying in the context of the current quality of the healthcare provided during childbirth in South Africa. The involuntary sterilisation of women during childbirth is an example of the broader issue of obstetric violence. ${ }^{128}$ One of the many recognised forms of obstetric violence is obstetric intervention during childbirth without informed consent, ${ }^{129}$ which practice pervades obstetric care in South Africa. ${ }^{130}$

Even though the broader issue of obstetric violence during childbirth has not made its way to the courts in South Africa, it might, and the $L M$ case could be particularly harmful if it were relied on by parties while litigating against involuntary sterilisations. Of further concern is the fact that the $L M$ case may be well received by judges when hearing involuntary sterilisation cases, thus making it a real possibility that the stereotype that women lack the capacity to provide informed consent as a result of labour pains may be entrenched in our law. Creating such an unfavourable and potentially harmful precedent could jeopardise the opportunity to develop the law in a way that dismantles the norms, stereotypes and broader structures that promote and perpetuate

128 Obstetric violence is recognised as a form of gender-based violence which can occur at an institutional level and a personal level. In Venezuela, art 15 of the Organic Law on the Right of Women to a Life Free from Violence, 2007 recognises obstetric violence as a form of violence that health personnel inflict on pregnant and birthing people. It defines it as the appropriation of the body and reproductive processes of women by health personnel which causes a loss of autonomy and the ability to decide freely about their bodies and sexuality, negatively impacting the quality of life of women. See D'Gregorio 2010 Int J Gynaecol Obstet 201.

129 Other examples of obstetric violence include physical, psychological and verbal abuse, humiliation, shouting, scolding, and crude and aggressive attacks on women's sexuality, performing clitordectomies and virginity inspections where consent is socially coerced and deliberate refusal of pain relief. See Pickles 2015 SAQC 6-7 and authority cited therein.

130 Jewkes, Abrahams and Mvo 1998 Soc Sci Med 1786; Farrell and Pattinson 2004 SAMJ 896; Kruger and Schoombee $2010 \mathrm{~J}$ Reprod Infant Psychol 94-97; Human Rights Watch 2011 https://www.hrw.org/sites/default/files/reports/sawrd0811 webwcover.pdf 24, 2934; Chadwick, Cooper and Harries 2014 Midwifery 865; Chadwick 2014 Afr J Midwifery Women's Health 177; Honikman, Fawcus and Meintjes 2015 SAMJ 284, Hastings, Nolte and Temane 2017 Women and Birth (in press). 
obstetric violence in South Africa. ${ }^{131}$ Thus, relying on the reasoning in the $L M$ case to support women's compensation claims for involuntary sterilisation may come at the price of sacrificing all women's reproductive rights during childbirth, and would do little to challenge the status quo, which enables the perpetuation of obstetric violence against women during childbirth.

\section{Conclusion}

In a society where women are still establishing their autonomous space for agency and substantive equality that results in transformation within obstetric care, it is counter-intuitive to support the $L M$ case and encourage its application to reproductive health issues in Namibia, South Africa, or elsewhere. This article demonstrates that the $L M$ case relies on and perpetuates the stereotype that women are incompetent decision makers during childbirth. The application of this stereotype harms and discriminates against women in childbirth since it functions to deny them their right to reproductive self-determination. It also fails to protect and promote reproductive rights more broadly, and it treats birthing women differently within the context of the requirement of informed consent. All of this occurs without considering the individuality of women and without the support of adequate evidence.

South Africa is still determining how the Bill of Rights applies in the context of childbirth. There is no legislation giving content to human rights relevant to pregnancy, labour or birth, there is very little litigation on human rights issues during childbirth, and there is little academic commentary. In this context the $L M$ case could have a fairly negative impact on the development of the foundation necessary for the effective promotion and protection of women's rights during childbirth and obstetric care in South Africa. Securing compensation for involuntary treatment should not cost women their rights during childbirth and should never be based on harmful stereotypes. Those developing litigation strategies and judicial officers should be cautious of the reasoning in the $L M$ judgment and should actively guard against perpetuating harmful stereotypes of women in childbirth.

131 This claim is linked to the argument that obstetric violence is a product of broader social inequalities linked to gender. For instance, Dixon, in relation to the Mexican experience of overcoming obstetric violence argues that the obstetric violence movement "positions specific obstetric practices within a broader framework of historical and ongoing patterns of social inequality, especially related to gender, race, and class. How women are treated in labor and birth ... mirrors how they are treated in society in general. For many midwives, this means that women are set up from the beginning to be treated poorly in public hospitals-because of their status as lower class and/or indigenous". Dixon 2015 Med Anthropol Q 447. 


\section{BIBLIOGRAPHY}

\section{Literature}

Albertyn 2007 SAJHR

Albertyn C "Substantive Equality and Transformation in South Africa" 2007 SAJHR 253-276

Appelbaum 2007 N Engl J Med

Appelbaum PS "Assessment of Patients' Competence to Consent to Treatment" 2007 N Engl J Med 1834-1840

Badul and Strode 2013 AHRLJ

Badul CJ and Strode A "LM and Others $v$ Government of the Republic of Namibia: The First Sub-Saharan African Case Dealing with Coerced Sterilisations of HIV-Positive Women - Quo Vadis?" 2013 AHRLJ 214-228

Bonnington et al 2013 Contraception

Bonnington A et al "Abortion Providers as Stigmatizers: Provider Judgment and Stereotyping of Patients Seeking Abortion" 2013 Contraception 443

Broaddus and Chandrasekhar 2011 Anesth Analg

Broaddus BM and Chandrasekhar S "Informed Consent in Obstetric Anesthesia" 2011 Anesth Analg 912-915

Brooks and Sullivan 2002 Int J Obstet Anesth

Brooks $\mathrm{H}$ and Sullivan WJ "The Importance of Patient Autonomy at Birth" 2002 Int J Obstet Anesth 196-203

Burrows 2012 Techné

Burrow S "Reproductive Autonomy and Reproductive Technology" 2012 Techné: Research in Philosophy and Technology 31-44

Cahill 1999 Nursing Ethics

Cahill H "An Orwellian Scenario: Court Ordered Caesarean Section and Women's Autonomy" 1999 Nursing Ethics 494-505

Carstens and Pearmain Foundational Principles

Carstens P and Pearmain D Foundational Principles of South African Medical Law (LexisNexis Durban 2007) 
Casarett, Karlawish and Hirschman 2003 J Pain Symptom Manage

Casarett DJ, Karlawish JHT and Hirschman KB "ldentifying Ambulatory Cancer Patients at Risk of Impaired Capacity to Consent to Research" $2003 \mathrm{~J}$ Pain Symptom Manage 615-624

Chadwick 2014 Afr J Midwifery Women's Health

Chadwick R "Raising Concerns: Quality of Care and Maternal Health Services in South Africa" 2014 Afr J Midwifery Women's Health 177-181

Chadwick, Cooper and Harries 2014 Midwifery

Chadwick RJ, Cooper D and Harries J "Narratives of Distress about Birth in South African Public Maternity Settings: A Qualitative Study" 2014 Midwifery 862-868

Cohen Shabot 2017 Eur J Women Stud

Cohen Shabot S "Constructing Subjectivity through Labour Pain: A Beauvoirian Analysis" 2017 Eur J Women Stud 128-142

Cook and Cusack Gender Stereotyping

Cook RJ and Cusack S Gender Stereotyping: Transnational Legal Perspectives (University of Pennsylvania Press Philadelphia 2010)

Cook, Cusack and Dickens 2010 Int J Gynaecol Obstet

Cook RJ, Cusack S and Dickens BM "Unethical Female Stereotyping in Reproductive Health" 2010 Int J Gynaecol Obstet 255-258

Cusack and Cook 2009 JCRSJ

Cusack S and Cook RJ "Stereotyping Women in the Health Sector: Lessons from CEDAW" 2009 JCRSJ 47-78

D'Gregorio 2010 Int J Gynaecol Obstet

D'Gregorio RP "Obstetric Violence: A New Legal Term Introduced in Venezuela" 2010 Int J Gynaecol Obstet 201-202

Dickens and Cook 2015 Int J Gynaecol Obstet

Dickens BM and Cook RJ "Patients' Refusal of Recommended Treatment" 2015 Int J Gynaecol Obstet 105-108

Dixon 2015 Med Anthropol Q

Dixon LZ "Obstetrics in a Time of Violence: Mexican Midwives Critique Hospital Practices" 2015 Med Anthropol Q 437-454 
Donnelly $2007 \mathrm{JSIJ}$

Donnelly M "Assessing Legal Capacity: Process and the Operation of the Functional Test" 2007 JSIJ 141-168

Essack and Strode 2012 Agenda

Essack Z and Strode A "'I Feel Like Half a Woman All the Time': The Impacts of Coerced and Forced Sterilisations on HIV-Positive Women in South Africa" 2012 Agenda 24-34

Farrell and Pattinson 2004 SAMJ

Farrell E and Pattinson RC "Out of the Mouths of Babes - Innocent Reporting of Harmful Labour Practices" 2004 SAMJ 896-897

Flanigan 2016 Ethical Theory Moral Pract

Flanigan J "Obstetric Autonomy and Informed Consent" 2016 Ethical Theory Moral Pract 225-244

Gerancher et al 2000 Int J Obstet Anesth

Gerancher JC et al "An Evaluation of Informed Consent Prior to Epidural Analgesia for Labor and Delivery" 2000 Int J Obstet Anesth 168-173

Gillmor 2000 Int J Childbirth Educ

Gillmor M "The Hazards of Stereotyping" 2000 Int J Childbirth Educ 8

Glennon "Regulation of Reproductive Decision-Making"

Glennon T "Regulation of Reproductive Decision-Making" in Sclater SD et al (eds) Regulating Autonomy: Sex, Reproduction and Family (Hart Oxford 2009) 149-168

Halliday Autonomy and Pregnancy

Halliday S Autonomy and Pregnancy: A Comparative Analysis of Compelled Obstetric Intervention (Routledge London 2016)

Hastings, Nolte and Temane 2017 Women and Birth (in press)

Hastings-Tolsma M, Nolte AG and Temane A "Birth Stories from South Africa: Voices Unheard" 2017 Women and Birth (in press)

Heaton South African Law of Persons

Heaton J The South African Law of Persons $4^{\text {th }}$ ed (LexisNexis Durban 2012)

Himonga "Persons and Family"

Himonga C "Persons and Family" in Du Bois F (ed) Wille's Principles of South African Law $9^{\text {th }}$ ed (Juta Cape Town 2007) 145-404 
Honikman, Fawcus and Meintjes 2015 SAMJ

Honikman S, Fawcus S and Meintjes I "Abuse in South African Maternity Settings is a Disgrace: Potential Solutions to the Problem" 2015 SAMJ 284

Hope 2005 Medicine

Hope T "Consent" 2005 Medicine 3-7

Jackson et al 2000 Can J Anesth

Jackson $\mathrm{A}$ et al "Informed Consent for Labour Epidurals: What Labouring Women Want to Know" 2000 Can J Anesth 1068-1073

Jewkes, Abrahams and Mvo 1998 Soc Sci Med

Jewkes R, Abrahams $\mathrm{N}$ and Mvo Z "Why do Nurses Abuse Patients? Reflections from South African Obstetric Services" 1998 Soc Sci Med 17811795

Johanson, Newburn and Macfarlane 2002 BMJ

Johanson R, Newburn $M$ and Macfarlane $A$ "Has the Medicalisation of Childbirth Gone too far?" 2002 BMJ 892-895

Kruger and Schoombee $2010 \mathrm{~J}$ Reprod Infant Psychol

Kruger $\mathrm{L}$ and Schoombee $\mathrm{C}$ "The Other Side of Caring: Abuse in a South African Maternity Ward" $2010 \mathrm{~J}$ Reprod Infant Psychol 84-101

Ladd 1989 Hypatia

Ladd RE "Women in Labor: Some Issues about Informed Consent" 1989 Hypatia 37-44

Lothain 2006 JOGNN

Lothain J "Birth Plans: The Good, the Bad, and the Future" 2006 JOGNN 295303

Murphy 2009 Ave Maria L Rev

Murphy SD "Labor Pains in Feminist Jurisprudence: An Examination of Birthing Rights" 2009 Ave Maria L Rev 443-471

Nair 2010 Harv Hum Rts $J$

Nair $\mathrm{P}$ "Litigating against the Forced Sterilisation of HIV-Positive Women: Recent Developments in Chile and Namibia" 2010 Harv Hum Rts J 223-231

Nicholas and Nicholas 2010 TOG

Nicholas N and Nicholas S "Understanding the Mental Capacity Act 2005: A Guide for Clinicians" 2010 TOG 29-34 
Patel 2017 Public Health Rev

Patel P "Forced Sterilization of Women as Discrimination" 2017 Public Health Rev 15-27

Pickles 2015 SAQC

Pickles C "Eliminating Abusive 'Care': A Criminal Law Response to Obstetric Violence" 2015 SAQC 5-16

Reid et al 2011 Aust N Z J Obstet Gynaecol

Reid $\mathrm{R}$ et al "The Ethics of Obtaining Consent in Labour for Research" 2011 Aust N Z J Obstet Gynaecol 485-492

Sekhar and Vyas 2013 Ann Med Health Sci Res

Sekhar MS and Vyas N "Defensive Medicine: A Bane to Healthcare" 2013 Ann Med Health Sci Res 295-296

Siegel 2008 Duke LJ

Siegel RB "The Right's Reasons: Constitutional Conflict and the Spread of Woman-Protective Antiabortion Argument" 2008 Duke LJ 1641-1692

Skegg 2011 U Queensland LJ

Skegg PDG "Presuming Competence to Consent: Could Anything be Sillier?" 2011 U Queensland LJ 165-187

Spence 2012 Cardozo JL \& Gender

Spence RA "Abandoning Women to their Rights: What Happens when Feminist Jurisprudence Ignores Birthing Rights" 2012 Cardozo JL \& Gender 101-123

Strode, Mthembu and Essack 2012 RHM

Strode A, Mthembu S, and Essack Z "'She Made Up a Choice for Me': 22 HIVPositive Women's Experiences of Involuntary Sterilization in Two South African Provinces" 2012 RHM 61-69

Tan 2002 Singapore Med J

Tan N "Deconstructing Paternalism - What Serves the Patient Best?" 2002 Singapore Med J 148-151

Thornton and Moore 1995 Int J Obstet Anesth Thornton $\mathrm{J}$ and Moore M "Controversies in Obstetric Anaesthesia" 1995 Int $\mathrm{J}$ Obstet Anesth 41-43 
Van Oosten Doctrine of Informed Consent

Van Oosten FL The Doctrine of Informed Consent in Medical Law (PhD thesis, University of South Africa 1989)

Wei 2016 Legal Issues

Wei $\mathrm{M}$ "The Illusion of Choice - Have Enforced Caesarean Cases Introduced a New Class of Incompetent Adults?" 2016 Legal Issues 85-98

\section{Case law}

AB v Minister of Social Development 20162 SA 27 (GP)

AB v Minister of Social Development 20173 SA 570 (CC)

AS v Hungary Com No 42004 (CEDAW C/36/D/4/2004, 29 August 2009)

Bolton Hospitals NHS Trust v O [2003] 1 FLR 824

Castell v De Greef 19944 SA 408 (C)

Christian Lawyers Association of SA v Minister of Health 19984 SA 1113 (T)

Christian Lawyers Association v Minister of Health 20051 SA 509 (T)

Geldenhuys v Borman 19901 SA 161 (E)

Gonzales v Carhart 550 US 124 (2007)

Government of the Republic of Namibia v LM [2014] NASC 19

LM v Government of the Republic of Namibia [2012] NAHC 211

Masiya v Director of Public Prosecutions 20075 SA 30 (CC)

NB v Slovakia App No 29518/10 (ECtHR, 12 June 2012)

Norfolk and Norwich Healthcare (NHS) Trust v W (1996) 34 BMLR 16

President of the Republic of Republic of South Africa v Hugo 19974 SA 1 (CC)

$\operatorname{Re} L$ (1996) 35 BMLR 44

Re MB [1997] EWCA Civ 3093

Re $T$ [1992] EWCA Civ 18 
Rochdale Healthcare (NHS) Trust v C [1997] 1 FCR 274

$S v$ Els 19931 SACR $723(0)$

S v Jordan 20026 SA 642 (CC)

S v Hangue 2016 JDR 0044 (NmS)

S v Rickerts 2016 JDR $0442(\mathrm{Nm})$

Tameside \& Glossop Acute Services Trust v CH [1996] 1 FLR 762

VC v Slovakia App No 18968/07 (ECtHR, 8 November 2011)

Volks v Robinson 20055 BCLR 446 (CC)

\section{Legislation}

Children's Act 38 of 2005

Choice on Termination of Pregnancy Act 92 of 1996

Constitution of the Republic of South Africa, 1996

Mental Capacity Act, 2005 (UK)

Organic Law on the Right of Women to a Life Free from Violence, 2007 (Venezuela)

Partial-Birth Abortion Ban Act, 2003 (US)

Sterilisation Act 44 of 1998

\section{Internet sources}

Kangaunde and Tucker date unknown http://www.womenslinkworldwide. org/files/gjo_summary_caseLMandOthersvNamibia_en.pdf

Kangaunde $\mathrm{G}$ and Tucker $\mathrm{P}$ date unknown Namibia SC Links Forced Sterilisation to Infringement of Constitutional Rights http://www.womenslinkworldwide.org/files/gjo_summary_caseLMandOthersv Namibia_en.pdf accessed 7 September 2016

HPCSA $2008 \quad$ http://www.hpcsa.co.za/downloads/conduct_ethics/ rules/generic_ethical_rules/booklet_9_informed_consent.pdf 
Health Professions Council of South Africa 2008 Guidelines for Good Practice in the Health Care Professions: Seeking Patients' Informed Consent: The Ethical Considerations http://www.hpcsa.co.za/downloads/conduct_ethics/ rules/generic_ethical_rules/booklet_9_informed_consent.pdf accessed 22 January 2018

Human Rights Watch 2011 https://www.hrw.org/sites/default/files/reports/ sawrd0811webwcover.pdf

Human Rights Watch 2011 Stop Making Excuses: Accountability for Maternal Health Care in South Africa https://www.hrw.org/sites/default/files/reports/ sawrd0811webwcover.pdf accessed 9 January 2017

WHO 2014 http://apps.who.int/iris/bitstream/10665/112848/1/978924 1507325_eng.pdf?ua $=1$

World Health Organisation 2014 Eliminating Forced, Coercive and Otherwise Involuntary Sterilization http://apps.who.int/iris/bitstream/10665/112848/1/ 9789241507325_eng.pdf?ua=1 accessed 28 February 2016

\section{LIST OF ABBREVIATIONS}

Afr $\mathrm{J}$ Midwifery Women's African Journal of Midwifery and Women's Health Health

AHRLJ

African Human Rights Law Journal

Anesth Analg Anesthesia and Analgesia

Ann Med Health Sci Res Annals of Medical and Health Sciences Research

Aust N Z J Obstet Australian and New Zealand Journal of Gynaecol Obstetrics and Gynaecology

Ave Maria L Rev Ave Maria Law Review

BMJ British Medical Journal

Can J Anesth Canadian Journal of Anaesthesia Cardozo JL \& Gender Cardozo Journal of Law and Gender CEDAW Committee on the Elimination of Discrimination against Women

Duke LJ

Duke Law Journal

ECtHR

Ethical Theory Moral Pract

European Court of Human Rights

Eur J Women Stud European Journal of Women's Studies Harv Hum Rts J Harvard Human Rights Journal 


$\begin{array}{ll}\begin{array}{l}\text { HPCSA } \\ \text { Int J Gynaecol Obstet }\end{array} & \begin{array}{l}\text { Health Professions Council of South Africa } \\ \text { International Journal of Gynecology and } \\ \text { Obstetrics } \\ \text { International Journal of Childbirth Education }\end{array} \\ \begin{array}{l}\text { Int J Childbirth Educ } \\ \text { Int J Obstet Anesth }\end{array} & \begin{array}{l}\text { International Journal of Obstetric Anesthesia } \\ \text { J Pain Symptom Manage }\end{array} \\ \begin{array}{l}\text { Journal of Pain and Symptom Management } \\ \text { J Reprod Infant Psychol } \\ \text { JCRSJ }\end{array} & \begin{array}{l}\text { Journal of Reproductive and Infant Psychology } \\ \text { Washington \& Lee Journal of Civil Rights and }\end{array} \\ \text { JOGNN } & \begin{array}{l}\text { Social Justice } \\ \text { Journal of Obstetric, Gynecologic and Neonatal }\end{array} \\ \text { JSIJ } & \text { Nursing } \\ \text { Med Anthropol Q } & \text { Judicial Studies Institute Journal } \\ \text { N Engl J Med } & \text { Medical Anthropology Quarterly } \\ \text { RHM } & \text { New England Journal of Medicine } \\ \text { Public Health Rev } & \text { Reproductive Health Matters } \\ \text { SAJHR } & \text { Public Health Reviews } \\ \text { SAMJ } & \text { South African Journal on Human Rights } \\ \text { SAQC } & \text { South African Medical Journal } \\ \text { Singapore Med J } & \text { South African Crime Quarterly } \\ \text { Soc Sci Med } & \text { Singapore Medical Journal } \\ \text { TOG } & \text { Social Science and Medicine } \\ \text { U Queensland LJ } & \text { The Obstetrician and Gynaecologist } \\ \text { WHO } & \text { University of Queensland Law Journal } \\ & \text { World Health Organization }\end{array}$

